\title{
Antimicrobial susceptibility of Salmonella serovars isolated from edible offal and carcasses of slaughtered poultry in the state of Tocantins, Brazil
}

\section{Susceptibilidade antimicrobiana de sorovares de Salmonella sp. isolados de vísceras comestíveis e carcaças de aves abatidas no estado do Tocantins, Brasil}

\author{
Silvia Minharro ${ }^{1 *}$; Cristiane Alves Nascimento ${ }^{2}$; Jean Paulo Galletti ${ }^{3}$; \\ Tainá Japiassú Merisse ${ }^{4}$; Adriana Carla Floresta Feitosa ${ }^{3}$; Helcileia Dias Santos ${ }^{1}$; \\ Francisca Elda Ferreira Dias ${ }^{1}$; Eliete Souza Santana ${ }^{5}$; Cristiane Divan Baldani ${ }^{6}$; \\ Maria Auxiliadora Andrade ${ }^{7}$
}

\begin{abstract}
The aim of this study was to evaluate the profile of antibiotic resistance in Salmonella isolated from the carcasses, livers and hearts of chickens slaughtered in the state of Tocantins, Brazil, as recommended by the Normative Instruction 70 of 2003 of the Ministry of Agriculture, Livestock and Food Supply and the National Monitoring Program Prevalence and Bacterial Resistance in Chicken. Carcasses, livers and hearts from chicken with or without pericarditis/perihepatitis were studied in 60 lots of poultry slaughtered under the Federal Inspection System in the state of Tocantins, Brazil between August 2010 and June 2011. Twenty-six indicative Salmonella sp. were isolated in 11 lots (18.33\%). Different strains of Salmonella were isolated more than a kind of sample/lot. The most frequent serovar was Enteriditis (38.46\%, 10/26), while the second was Mbandaka (19.23\%, 5/26), both isolated from hearts, livers and carcasses. Regarding antimicrobial resistance, of 12 tested principal pharmacological agents, the samples appeared to be most sensitive to tetracyclines, but showed $100 \%$ resistance to one or more active principal agents, especially sulfamethoxazole $(30 \mathrm{mcg})$ and amoxicillin/clavulanic acid $(30 \mathrm{mcg})$. Although Salmonella sp. was isolated from normal carcasses, the results are within permitted levels for unfrozen products according to Brazilian legislation. However, one should always be aware of the hygienic and sanitary conditions of production processes and food processing, especially regarding good manufacturing practices.
\end{abstract}

Key words: Chicken, inspection, salmonellosis

\footnotetext{
${ }^{1}$ Profs., Drs., Universidade Federal do Tocantins, Escola de Medicina Veterinária e Zootecnia, EMVZ/ UFT, Araguaina, TO, Brasil.E-mail: silviaminharro@yahoo.com.br; diasfef@gmail.com; hdsantos@uft.edu.br

2 Pesquisadora, UFT, Araguaína, TO. Brasil. E-mail: crisalves_9@hotmail.com

${ }^{3}$ Médicos Veterinários, Ministério da Agricultura, Pecuária e Abastecimento, SISA, Palmas, TO, Brasil. E-mail: jjgalletti@ hotmail.com; adriana.floresta@agricultura.gov.br

${ }^{4}$ Discente de Graduação, Medicina Veterinária, Iniciação Cientifica-CNPQ, Universidade Federal do Tocantins, UFT, Araguaína, TO, Brasil. E-mail: taina.jm@hotmail.com

${ }^{5}$ Prof ${ }^{\mathrm{a}}$, M.e, Universidade Estadual de Goiás, UnU, Palmeiras de Goiás, GO. Brasil. E-mail: elietesouza@yahoo.com.br

${ }^{6}$ Prof $^{\mathrm{a}} \mathrm{Dr}^{\mathrm{a}}$, Universidade Federal Rural do Rio de Janeiro, Instituto de Veterinária, UFRRJ, Seropédica, RJ, Brasil. E-mail: crisbaldani@gmail.com

${ }^{7}$ Prof $^{a}$ Dr $^{a}$ Titular, Universidade Federal de Goiás, Escola de Veterinária e Zootecnia, UFG, Goiânia, GO, Brasil. E-mail: maa@ ufg.br

* Author for correspondence
} 


\section{Resumo}

Com o objetivo de observar os parâmetros estabelecidos pela Instrução Normativa 70 de 2003 do Ministério da Agricultura Pecuária e Abastecimento, juntamente com o Programa Nacional de Monitoramento da Prevalência e da Resistência Bacteriana em Frango, o qual prevê o monitoramento de Salmonella sp. em produtos de frangos resfriados, foram estudadas carcaças e miúdos comestíveis (fígados e coração), condenados ou não por pericardite/perihepatite, em 60 lotes de aves abatidos sob Sistema de Inspeção Federal no estado do Tocantins, entre agosto de 2010 a junho de 2011. Foram isoladas 26 amostras indicativas de Salmonella sp. em 11 lotes (18,33\%), sendo mais de uma estirpe por tipo de amostra. Os sorovares de maior frequência foram o Enteriditis $(38,46 \% ; 10 / 26)$ e Mbandaka $(19,23 \% ; 5 / 26)$, ambos isolados de coração, fígado e carcaça. Quanto ao perfil de resistência aos antimicrobianos, foram testados 12 princípios farmacológicos e as amostras apresentaram-se diferenciadas em alguns aspectos do encontrado na literatura consultada, sendo a maioria sensível às tetraciclinas, porém apresentaram $100 \%$ de resistência a um ou mais principio ativo, principalmente para Sulfamethoxazole $(30 \mathrm{mcg})$ e Amoxicilina/Ácido Clavulânico (30 mcg). Apesar da Salmonella sp. ter sido isolada em carcaças normais, os resultados encontram-se dentro do permitido pela legislação brasileira vigente para produtos que ainda não sofreram processo de congelação. No entanto, deve-se sempre estar atento às condições higiênicas e sanitárias dos processos de produção e processamento de alimentos, principalmente quanto às boas práticas de fabricação.

Palavras-chave: Frango, inspeção, salmonelose

\section{Introduction}

Chicken meat is a food of animal of major importance in the Brazilian diet; $68.4 \%$ of chicken production in 2013 was for human consumption, with an average of 42 pounds per person (UBABEF, 2014). In Brazil, poultry slaughter under the Federal Inspection Service (SIF) is concentrated mainly in the south, southeast and central-west regions of the country. In the north, only two states have SIF slaughterhouses, i.e. Pará and Tocantins (UBABEF, 2014). Although the state of Tocantins have low expression in national production $(0.24 \%)$, it is enough to production to supply the domestic market beyond the states of Maranhão and Pará “. However, if the slaughtering process is not accomplished hygienically, or in cases of accidents, carcasses and edible offal can be contaminated (OLIVEIRA et al., 2012). Moreover, the contamination of these products can result in severe economic losses caused by the impossibility of trade (SHINOHARA et al., 2008).

Brazil has an integrated service for the surveillance, prevention and control of foodborne diseases, in particular those caused by Salmonella sp. which is one of the most common etiologic agents associated with outbreaks of bacterial origin (BRASIL, 2010). It is estimated that salmonellosis causes 1.2 million illnesses annually in the United States, with more than 23,000 hospitalizations and 450 deaths (SCALLAN et al., 2011). Among the characteristic aspects of Salmonella sp. epidemiology, increases in antimicrobial resistance, its intersection with AIDS, and the prevalence of infections by Salmonella enterica subsp. enterica serovar Enteritidis ( $S$. Enteritidis) are associated with the consumption of animal foods and the occurrence of scattered outbreaks (JAY, 2005).

To carry out the monitoring of Salmonella contamination in a poultry slaughterhouse, considering its importance in public health and the possible trade barriers, the Ministry of Agriculture, Livestock and Food Supply (MAPA) established by Normative Instruction No. 70, the "reduction program pathogens - microbiological monitoring and control Salmonella sp. carcasses of chickens and turkeys -PREBAF" (BRASIL, 2003b). In 2004, the National Agency for Sanitary Vigilance (ANVISA) implemented the National Program for Monitoring 
Prevalence and Bacterial Resistance in Chicken, whose main objective is to monitor antibiotic resistance in Salmonella sp. and Enterococcus sp. isolated from humans, animals and food.

Thus, the aim of this study was to identify the major serovars of Salmonella and the antibiotic resistance profile of isolates from chicken carcasses and organs (heart and liver) with lesions suggestive of salmonellosis (pericarditis and perihepatitis) as well as chicken carcasses released for consumption, slaughtered in the state of Tocantins.

\section{Material and Methods}

For this study, 300 carcasses 600 hearts and 600 livers were collected originated that 60 lots of chicken, from states of Tocantins, Goiás, Distrito Federal and São Paulo, but they were slaughtered in the state of Tocantins under SIF regulations, in the period from August 2010 to June 2011.

For the analysis of viscera, livers and hearts were collected from 10 chickens per lot, as well as 10 livers and 10 hearts from lots with confirmed pericarditis and hepatitis and 10 normal livers and 10 hearts of lots released for consumption. The hearts and livers were processed in pools of five, for a total of 4 samples per batch (two normal and two infected). The infected carcasses were collected at the time of post mortem inspection, while the liberated carcasses were collected after pre-cooling sections individually, with a total of five carcasses per lot. These were immediately placed in sterile, labeled plastic containers and sent for laboratory analysis. Carcasses were processed by the rinsing method (COX et al., 1978), in which the five carcasses were immersed in turn in a same sterile plastic bag containing $500 \mathrm{~mL}$ of phosphate buffered saline (1x PBS), forming one pool (REZENDE et al., 2008).

Isolation and identification of Salmonella sp. were performed as recommended by the MAPA protocol (BRASIL, 2003a). Salmonella isolates were sent to the National Reference Laboratory for Bacterial Intestinal Infections at the Oswald CruzFiocruz Foundation for serotyping.

The antimicrobial profile was performed according the National Committee for Clinical Laboratory Standards (NCCLS, 2011). The antimicrobials used were amoxicillin/clavulanic acid (30 mcg), ampicillin (10 mcg), ceftiofur (30 $\mathrm{mcg}$ ), ciprofloxacin (5 mcg), doxycycline (30 $\mathrm{mcg}$ ), enrofloxacin (5 mcg), gentamicin (10 mcg), oxytetracycline (30 mcg), sulfamethoxazole (30 $\mathrm{mcg}$ ), trimethoprim/sulfamethoxazole (25 $\mathrm{mcg})$, sulfonamide $(300 \mathrm{mcg})$ and tetracycline $(30 \mathrm{mcg})$. The reading of inhibition zones was performed with the use of a millimetric ruler, comparing the values obtained with the standard table. The results were evaluated by simple and relative frequency (SAMPAIO, 2007).

\section{Results and Discussion}

Of the sixty lots evaluated for the presence of Salmonella sp., there were 11 lots were positives, representing $18.33 \%(11 / 60)$ of the lots studied. Of these positive batches, in five $(5 / 11=45.45 \%)$ was isolated $(8.33 \%)$, Salmonella sp. from apparently normal organs (released batches), while the other six $(10 \%)(6 / 11=54.55 \%$ were isolated from contained infected carcasses (perihepatitis or pericarditis). The frequency of Salmonella sp. no infected carcasses, i.e. $8.33 \%(5 / 60)$, was similar to that described in five processing plants in northeastern Brazil by Duarte et al. (2009), who found that $9.6 \%$ of whole chickens were contaminated with Salmonella sp. Boni et al. (2011) studied samples in the field and in abattoirs in Mato Grosso do Sul, and found that $9.8 \%$ of samples were contaminated with Salmonella sp. In contrast, Rezende et al. (2005) evaluated the presence of Salmonella sp. in the carcasses of broilers raised in Goiás, of which $19.8 \%$ were contaminated. Carvalho and Cortez (2005) isolated Salmonella sp. in $16.67 \%$ of cold carcasses from an abattoir in São Paulo. 
From the positive batches, 26 strains of Salmonella were isolated; these were divided into 11 heart samples $(42.30 \%, 11 / 26), 10$ liver samples $(38.46 \%, 10 / 26)$ and five carcasses $(19.23 \%$, $5 / 26)$; i.e. more than one strain was per lot and/or kind of sample. Of these, 11 isolates were found in released viscera and 15 in contaminated samples. Of these 26 samples of Salmonella sp., nine serotypes were identified. The serovar Enteritidis was the most frequently isolated $(38.46 \%, 10 / 26)$ from the viscera and carcasses, but was found only in broilers from Goiás; the second most frequent was Mbandaka $(19.23 \%, 5 / 26)$, isolated from the hearts, livers and carcasses in lots from the states of Goiás, Tocantins and São Paulo (Table 1). Less frequently, the serovar Agona $(7.7 \%, 2 / 26)$ was identified in hearts isolated from chickens from the state of São Paulo, and the serovar Infantins $(7.7 \%, 2 / 26)$ was isolated from the viscera, hearts and livers of poultry that originated in São Paulo (Table 1). Less frequent serovars were Anatum $(3.84 \%, 1 / 26)$, isolated from carcasses, Minnesota $(3.84 \%, 1 / 26)$ isolated from the livers of chickens from Goiás, and Panama $(3.84 \%, 1 / 26)$, isolated from livers that originated from São Paulo (Table 1).

Table 1. Identification of Salmonella serovars according to the state of origin of lots and kind of samples of chickens slaughtered in Tocantins, Brazil from August 2010 to June 2011.

\begin{tabular}{lcccc}
\hline Salmonella serovar & Kind of samples & state of origin* & number of isolates & $\%$ \\
\hline Agona & heart & SP & 2 & 7.70 \\
Anatum & carcass & GO & 1 & 3.84 \\
Enteritidis & heart, liver and carcass & GO & 10 & 38.48 \\
Infantis & heart and liver & SP & 2 & 7.70 \\
Mbandaka & heart, liver and carcass & GO, SP and TO & 5 & 19.23 \\
Minnesota & liver & GO & 1 & 3.84 \\
Orion & heart, liver and carcass & GO and TO & 3 & 11.53 \\
Panama & liver & SP & 1 & 3.84 \\
Schwarzengrund & heart & GO & 1 & 3.84 \\
\hline TOTAL & & & 26 & 100.00 \\
\hline
\end{tabular}

* GO: Goiás; SP: São Paulo; TO: Tocantins.

In Table 1, it can be seen that greatest distribution of serovars among states. The serovar Mbandaka was found in three states with positive isolates (Goiás, Tocantins and São Paulo); Orion was isolated from samples from Tocantins and Goiás. One can also note that all states with isolated Salmonella had more than one serovar. The samples from Goiás had a greater diversity of serotypes, with six identified (Anatum, Enteritidis, Mbandaka, Minnesota, Orion and Schwarzengrund); the state of São Paulo had four of the nine serotypes (Agona, Infantis, Mbandaka and Panama). In Tocantins, two serovars (Mbandaka and Orion) were found.
Comparing our findings with data acquired in Goiás (MOREIRA et al., 2008), northeastern Brazil (DUARTE et al., 2009), Mato Grosso do Sul (BONI et al., 2011) and Rio Grande do Sul (BORSOI et al., 2010), it was found that the most common serotypes are Salmonella Enteritidis, Salmonella Mbandaka, Salmonella Infantis, Salmonella Schwarzengrund and Salmonella Albany. Salmonella Typhimurium and Salmonella Heldelberg was also present in the other, but was not identified in this work. According to the National Agency for Sanitary Vigilance (ANVISA), serovars Salmonella Enteritidis, Salmonella Infantis, Salmonella Typhimurium, 
Salmonella Heidelberg and Salmonella Mbandaka are the most prevalent in frozen carcasses in Brazil (BRASIL, 2008). According to Sant'ana et al. (2008), it is known that the prevalence of Salmonella serotypes in birds changes from year to year, but several serotypes are consistently found with high incidence, such as Salmonella Heldelberg, Salmonella Enteritidis and Salmonella Typhimurium.

In 2002, 2003 and 2004, the Fiocruz Laboratory characterized Salmonella Enteritidis as the most frequent serovar in poultry, and registered a high occurrence in 2004 (RODRIGUES, 2005). These findings are of concern since this serotype has been reported more frequently in cases of infections in humans and in other countries associated with poultry products (CDC, 2011; MARIN et al., 2011).

These data show the difficulty of controlling Salmonella sp. in slaughterhouses, especially at critical control points, since contamination can be caused during several slaughter operations such as scalding, plucking and evisceration (VON RUCKERT et al., 2009). Another critical point of contamination can be inputs from feed of animal origin such as bone meal and feathers, fish and offal.

Even with the technological advances in health monitoring, salmonellosis ranks highly among the causes of gastroenterocolitis, notably due to its characteristics such as endemicity, morbidity and, in particular, the difficulty in control (JAY, 2005). According to Oliveira et al. (2012), broilers are among the most important carriers of pathogens in slaughterhouses, and they constitute an important reservoir and show a high correlation with crosscontamination by Salmonella sp. This has been a concern for MAPA which has established constant monitoring of the level of contamination by this pathogen in poultry slaughterhouses, i.e. the Program for the reduction of pathogens - microbiological monitoring and control of Salmonella sp. in carcasses of chickens and turkeys, also known as
IN 70 (BRASIL, 2003b). According to IN 70, the findings of this study are within the tolerable limits of acceptance, which says that in 51 samples, corresponding to the number of plots sampled in a year (one cycle), a maximum of 12 positive samples $(c=12)$ is allowed (BRASIL, 2003b).

In carcasses from 0 to 24 hours after immersion in the precooling solution, Canson et al. (2006) observed an increase in Salmonella sp. positivity. Von Ruckert et al. (2009) reported that visceral rupture during evisceration contributes to a higher frequency of Salmonella sp. in carcasses. Rezende et al. (2008) commented that, due to market trends, the agribusiness produces edible offal products that are widely accepted by consumers, requiring relevant microbiological investigations of these parts along with carcasses and other products. In the state of Goiás, Rezende et al. (2008) found 4.34\% positive lots of normal and contaminated hearts, although Salmonella was not isolated in the normal heart. In the present study, $11.66 \%$ of positive lots of this organ were contaminated with Salmonella. Salmonella was isolated from $10 \%$ of the liver lots. These results were lower than the results found in the same study by Rezende et al. (2008), who isolated Salmonella sp. in $18.91 \%$ of contaminated livers. Salmonella Typhimurium was isolated in contaminated livers only, accounting for $5.56 \%$ positivity in this type of sample. Baú et al. (2001) found in their study five contaminated samples out of 44 analyzed $(11.36 \%)$ in the city of Pelotas in southern Brazil; however, these samples included the viscera (heart, liver and gizzard) and not only the heart or liver. In the state of Mato Grosso do Sul, Boni et al. (2011) found five positive results in 25 samples $(20 \%)$.

IN 70 does not provide for monitoring viscera; however, the results show that Salmonella sp. remains a persistent contamination problem in poultry products. Further improvements are required in programs for disease prevention, especially since the viscera are not covered by the legislation. 
Among the most commonly used products is chicken heart, which can be a carrier of Salmonella sp. Hearts are normally consumed baked, which fails to complete inactivation of the pathogen, because the heat does not penetrate deep enough into the viscera; this can result in contamination and a risk of infection for the consumer (REZENDE et al., 2008).

The possible contamination of the liver, as explained by Gomes et al. (2014), occurs due to the stress required during the production cycle of chickens that make them susceptible to the migration of Salmonella enteritidis to the liver and spleen. After breaking the intestinal immune barrier, the decrease in immune efficiency is possibly mediated by activation of the hypothalamic-pituitary-adrenal and increased levels of corticosterone.

Regarding the antimicrobial resistance of 12 principal pharmacological agents, $100 \%$ of the isolates tested were resistant to one or more active principal agent. All samples (100\%) were sensitive to ciprofloxacin, doxycycline, oxytetracycline (30 mcg), tetracycline and sulfamethoxazole/ trimethoprim. But on the other hand $100 \%$ of the samples were resistant to sulfamethoxazole (30 $\mathrm{mcg}$ ) and amoxicillin/clavulanic acid (30 $\mathrm{mcg})$ (Table 2). Fourteen samples $(53.84 \%, 14 / 26)$ were resistant to sulfonamide (300 $\mathrm{mcg}$ ), including the serovars Mbandaka, Anatum, Infantis, Panama, Enteriditis and Minnesota. Six had intermediate sensitivity $(23.07 \%, 6.26)$, including the serovars Enteritidis, Mbandaka, Schwarzengrund and Oriom (the intermediate results were not shown). Regarding enrofloxacin, one sample (Mbandaka) was resistant and five (all serovar Enteritidis) were intermediate. For ceftiofur (30 mcg), one sample (Agona) was resistant and two (Enteritidis and Mbandaka) were intermediate. For gentamycin, one sample (Orion) was resistant and two (Mbandaka and Orion) were intermediate. For Ampicillin, two samples (Enteritidis and Mbandaka) were intermediate.

Table 2. Antimicrobial resistance of Salmonella sp. isolated from carcasses and offal (liver and heart) from apparently normal and infected chickens slaughtered in Tocantins, Brazil, from August 2010 to June 2011.

\begin{tabular}{|c|c|c|c|c|c|c|c|c|c|c|c|c|c|}
\hline \multirow{2}{*}{$\begin{array}{l}\text { Salmonella } \\
\text { serovar }\end{array}$} & \multirow{2}{*}{$\begin{array}{c}\text { Total } \\
\text { samples } \\
\text { tested }\end{array}$} & \multicolumn{12}{|c|}{ Number of samples resistant to the antimicrobial agent } \\
\hline & & DO & ENR & SAM & EFT & OT & $\mathrm{RL}$ & CIP & S3 & $\mathrm{CN}$ & $\mathrm{TE}$ & SXT & AMC \\
\hline Agona & 2 & & & & 1 & & 2 & & 2 & & & & 2 \\
\hline Anatum & 1 & & & & & & 1 & & 1 & & & & 1 \\
\hline Enteritidis & 10 & & & & & & 10 & & 4 & & & & 10 \\
\hline Infantis & 2 & & & & & & 2 & & 2 & & & & 2 \\
\hline Mbandaka & 5 & & 1 & & & & 5 & & 3 & & & & 5 \\
\hline Minnesota & 1 & & & & & & 1 & & 1 & & & & 1 \\
\hline Orion & 3 & & & & & & 3 & & & 1 & & & 3 \\
\hline Panama & 1 & & & & & & 1 & & 1 & & & & 1 \\
\hline Schwarzengrund & 1 & & & & & & 1 & & & & & & 1 \\
\hline TOTAL & 26 & 0 & 1 & 0 & 1 & 0 & 26 & 0 & 14 & 1 & 0 & 0 & 26 \\
\hline
\end{tabular}

$\mathrm{DO}=$ doxycycline $(30 \mathrm{mcg}) ; \mathrm{ENR}=$ enrofloxacin $(5 \mathrm{mcg}) ; \mathrm{SAM}=\operatorname{ampicillin}(10 \mathrm{mcg})$; EFT = ceftiofur $(30 \mathrm{mcg}) ; \mathrm{OT}=\operatorname{ampicillin}$ $(10 \mathrm{mcg}) ; \mathrm{RL}=$ sulfamethoxazole $(30 \mathrm{mcg}) ; \mathrm{CIP}=\operatorname{ciprofloxacin}(5 \mathrm{mcg}) ; \mathrm{S} 3=$ sulfonamide $(300 \mathrm{mcg}) ; \mathrm{CN}=\mathrm{gentamicin}(10 \mathrm{mcg})$; $\mathrm{TE}=$ tetracycline $(30 \mathrm{mcg}) ; \mathrm{SXT}=$ trimethoprim/sulfamethoxazole $(25 \mathrm{mcg}) ; \mathrm{AMC}=$ amoxicillin $/ \mathrm{clavulanic}$ acid $(30 \mathrm{mcg})$.

Due to the abuse of antibiotic drugs in both human medicine and veterinary medicine, many of these serovars have contributed to the selection of resistant microorganisms and the consequent 
increase in this characteristic vertically or horizontally between populations. Recently, changes have been made in the treatment of this disease, with the group of fluoroquinolones and third generation cephalosporins as the current treatment of choice (WHO, 2002).

The difficulty in treating salmonellosis may be associated with the inappropriate use of antimicrobials in poultry production, where resistant bacteria can transfer resistance factors to other pathogenic enterobacteria (GÓRNIAK; SPINOSA, 2007). However, outbreaks of Salmonella sp. occur sporadically, and the same phage type with an identical multidrug resistance profile has been identified in humans and farm animals (VAN DEN BOGAARD; STOBBERINGH, 2000). In chickens, the main antimicrobials used are sulfonamides, penicillins, polypeptides, lincosamides, cephalosporins and quinolones (GUARDABASSI et al., 2010). In agreement with the results obtained in our study, the majority of Salmonella serovars were resistant to the sulfonamide group (sulfamethoxazole and sulfonamide) and beta-lactam antibiotics (amoxicillin/clavulanic acid).

According to the PREBAF report (BRASIL, 2008), the major antibiotics to which Brazilian isolates have shown resistance, in descending order from 2004 to 2008, are streptomycin, sulfonamide, florfenicol, ampicillin, nalidixic acid, ceftiofur, aztreonam, enrofloxacin, cephalothin and cefoxitin.

Duarte et al. (2009) studied the profile of antimicrobial susceptibility of Salmonella sp. isolated from poultry slaughtered in the Brazilian northeast region found that $94.7 \%$ of strains were resistant to one or more antimicrobials. They found $31.6 \%$ of the tetracycline resistant strains $(10.5 \%)$ ampicillin, (10.5\%), enrofloxacin (5.2\%) for ciprofloxacin alone (10.5\%), amoxicillin/clavulanic acid and $5.2 \%$ to trimethoprim/sulfamethoxazole, while in our work, the samples were $100 \%$ resistant to the latter two drugs and sensitive to the others.
Rezende et al. (2005) noted the occurrence of multiple resistance and cross among 14 antimicrobials used in poultry and humans in strains isolated from broiler carcasses from slaughterhouses in the state of Goiás. The isolates were resistant to tetracycline ( $84.2 \%$ ), streptomycin (5.3\%), aztreonam (10.5\%) and ampicillin (36.8\%), sulphazotrim (15.8\%), chloramphenicol (5.3\%), cefoxitin $(26.3 \%)$ and cephalothin (10.5\%). While resistance was not found for polymyxin B, amikacin, netilmicin, gentamicin, norfloxacin or tobramycin.

In the city of Alfenas-MG, Coelho et al. (2012) found 100\% strains of Salmonella isolated from poultry cuts were resistant to tetracycline, sulphazotrim, (trimethoprim/sulfamethoxazole), amikacin, chloramphenicol, cefaxicitin and 8.2\% resistance to ampicillin and tobramycin.

In the work described above, there were differences, especially for tetracycline, sulphazotrim, ciprofloxacin and for ampicillin resistant, while our study, all samples were sensitive for these drugs. This fact may reflect the search for the appropriate use of antibiotics or distribution of a distinct pattern for this region / time. There is a consensus that the resistance pattern of enterobacteria depend on the season, region, serotype, farm, hens and chickens and antimicrobial agent (GYLES, 2008).

\section{Conclusion}

The results find in this work are in accordance with Brazilian law, however it is need to improve the quality control measures for Salmonella in poultry slaughterhouses, because there may be flaws in the inspection process, extending to the production system, Since this study were isolated important serovars of Salmonella sp. reported in the literature associated with public health, and all the strains showed multi-resistance profile, a fact that emphasizes the need for prudent and judicious use of these drugs in animal production. As well highlights the importance of agricultural fiscal 
policies and post-mortem inspection for sentinel diseases, especially zoonoses, and underscores the importance of routine monitoring within abattoirs to minimize the loss of product released during processing and marketing.

\section{References}

BAÚ, A. C.; CARVAlHaL, J. B.; ALEIXO, J. A. G. Prevalência de Salmonella em produtos de frandos e ovos de galinha comercializados em Pelotas, RS, Brasil. Ciência Rural, Santa Maria, v. 31, n. 2, p. 303-307, 2001.

BONI, H. F. K.; CARRIJO, A. S.; FASCINA, V. B. Ocorrência de Salmonella spp. em aviários e abatedouro de frangos de corte na região central de Mato Grosso do Sul. Revista Brasileira de Saúde Produção Animal, Salvador, v. 12, n. 1, p. 84-95, 2011.

BORSOI, A.; MORAES, H. L. S.; SALlE, C. T. P.; NASCIMENTO, V. P. Número mais provável de Salmonella isoladas de carcaças de frango resfriadas. Ciência Rural, Santa Maria, v. 40, n. 11, p. 2338-2342, 2010.

BRASIL. Ministério da Agricultura, Pecuária e Abastecimento. Instrução Normativa $\mathrm{N}^{\circ} 62$, de 26 agosto de 2003 do Poder Executivo. Oficializa os métodos analíticos oficiais para análises microbiológicas para controle de produtos de origem animal e água. Diário Oficial [da] República Federativa do Brasil, Brasília, 18 set. 2003a. Seção 1, p. 14.

Ministério da Agricultura, Pecuária e Abastecimento. Instrução Normativa $\mathrm{N}^{\circ} 70$, de 10 outubro de 2003. Regulamento do Programa de Redução de Patógenos Monitoramento Microbiológico e Controle de Salmonella sp. em Carcaças de Frangos e Perus. Diário Oficial [da] República Federativa do Brasil, Poder Executivo, Brasília, 10 out. 2003b. Seção 1, p. 9.

Ministério da Saúde, Agência Nacional de Vigilância Sanitária. Programa Nacional de Monitoramento da prevalência e da resistência (PREBAF). Relatório do monitoramento da prevalência e do perfil de suscetibilidade aos antimicrobianos em enterococos e salmonelas isoladas de carcaças de frango congeladas comercializadas no Brasil. Manual... Brasília: ANVISA, 2008. 188 p. Available at: <http:// www.anvisa.gov.br/alimentos/relatorios/relatorioprebaf. pdf $>$. Accessed at: 18 ago. 2012.

Ministério da Saúde. Secretaria de Vigilância em Saúde. Departamento de Vigilância Epidemiológica. Manual integrado de vigilância, prevenção e controle de doenças transmitidas por alimentos. Brasilia: Editora MS, 2010. 160 p. Available at: <http://bvsms.saude. gov.br/bvs/publicacoes/manual_integrado_vigilancia_ doencas_alimentos.pdf $>$. Accessed at: 18 ago. 2012.

CANSON, J. A.; BERRANG, M. E.; SMITH, D. P. Recovery of bacteria from broiler carcasses rinsed zero and twenty four hours after immersion chilling. Poultry Science, Savoy, v. 85, n. 2, p. 333-336, 2006.

CARVALHO, A. C. F. B.; CORTEZ, A. L. L. Salmonella spp. em carcaças, carne mecanicamente separada, linguiças e cortes comerciais de frango. Ciência Rural, Santa Maria, v. 35, n. 6, p. 1465-1468, 2005.

CENTER DISEASE CONTROL - CDC. National enteric disease surveillance: Salmonella surveillance overview. Atlanta: CDC, 2011. Available at: $<$ http://www.cdc.gov/nationalsurveillance/PDFs/ NationalSalmSurveillOverview_508.pdf $>$. Accessed at: 18 ago. 2012.

COELHO, D. A.; SILVA, P. M. F.; FIORINI, J. E.; VEIGA, S. M. O. M. Ocorrência de Salmonella sp. em cortes de frango e suscetibilidade aos antimicrobianos utilizados na terapia humana. Higiene Alimentar, São Paulo, v. 26, n. 204/205, p. 132-137, 2012.

COX, N. A.; MERCURI, A. J.; TANNER, D. A.; CARSON, M. O.; THOMSON, J. E.; BAILEY, J. S. Effectiveness of sampling methods for Salmonella detection on processed broilers. Journal of Food Protection, Des Moines, v. 41, n. 5, p. 341-343, 1978.

DUARTE, D. A. M.; RIBEIRO, A. R.; VASCONCELOS, A. M. M.; SANTOS, S. B.; SILVA, J. V. D.; ANDRADE, P. L. A.; FALCÃO, L. S. P. C. A. Occurrence of Salmonella spp. in broiler chicken carcasses and their susceptibility to antimicrobial agents. Brazilian Journal of Microbiology, São Paulo, v. 40, n. 3, p. 569-573, 2009.

GOMES, A. V. S.; QUINTEIRO-FILHO, W. M.; RIBEIRO, A.; FERRAZ-DE-PAULA, V.; PINHEIRO, M. L.; BASKEVILLE, E.; KAMINE, A. T. A.; ASTOLFIFERREIRA, C. S.; FERREIRA, A. J. P.; PALERMONETO, J. Overcrowding stress decreases macrophage activity andincreases Salmonella Enteritidis invasion in broiler chickens. Avian Pathology, Cambridge, v. 43, n. 1, p. 82-90, 2014.

GÓRNIAK, S. L.; SPINOSA, H. S. Antimicrobianos na avicultura - usos e restrições. In: ANDREATTI FILHO, R. L. Saúde aviária e doenças. São Paulo: Rocca, 2007. p. 35-40.

GUARDABASSI, L.; JENSEN, L. B.; KRUSE, H. Guia de antimicrobianos em veterinária. Porto Alegre: Artmed, 2010. 268 p. 
GYLES, C. L. Antimicrobial resistance in selected bacteria from poultry. Animal Health Research Reviews, Cambridge, v. 9, n. 2, p. 149-58, 2008.

JAY, J. M. Microbiologia de alimentos. 6. ed. Porto Alegre: Artmed, 2005. 712 p.

MARIN, C.; BALASCHC, S.; VEGAB, S.; LAINEZA, M. Sources of Salmonella contamination during broiler production in Eastern Spain. Preventive Veterinary Medicine, Amsterdam, v. 98, n. 1, p. 39-45, 2011.

MOREIRA, G. N.; REZENDE, C. S. M.; CARVALHO, R. N.; MESQUITA, S. Q. P.; OLIVEIRA, A. N.; ARRUDA, M. L. T. Ocorrência de Salmonella sp. em carcaças de frangos abatidos e comercializados em municípios do estado de Goiás. Revista do Instituto Adolf Lutz, São Paulo, v. 62, n. 2, p. 126-130, 2008.

NATIONAL COMMITTEE FOR CLINICAL LABORATORY STANDARDS - NCCLS. Bacterial from animal. Pennsylvania: NCCLS, 2011. 81 p.

OLIVEIRA, A. P.; SOLA, M. C.; FEISTEL, J. C.; REZENDE, C. S. M.; FAYAD, A. R. Salmonella sp. e o abate de frangos: pontos críticos de controle. Enciclopédia Biosfera- Centro Cientifico Conhecer, Goiânia, v. 8, n. 14, p. 865-875, 2012.

REZENDE, C. S. M.; ANDRADE, M. A.; MESQUITA, A. J.; COELHO, K. O.; MINAFRA, C. S.; ARRUDA, M. L. T.; LAGE, M. E. Salmonella sp. em corações e fígados normais e condenados de frangos de corte abatidos no estado de Goiás e identificação da suscetibilidade a antimicrobianos. Revista Instituto Adolfo Lutz, São Paulo, v. 67, n. 2, p. 142-147, 2008.

REZENDE, C. S. M.; MESQUITA, A. J.; ANDRADE, M. A.; LINHARES, G. F. C.; MESQUITA, A. Q.; MINAFRA, C. S. Sorovares de Salmonella isolados de carcaças de frangos de corte abatidos no Estado de Goiás, Brasil, e perfil de resistência a antimicrobianos. Revista Portuguesa de Ciências Veterinárias, Lisboa, v. 100, n. 555-556, p. 199-203, 2005.

RODRIGUES, D. P. Ecologia e prevalência de Salmonella spp. em aves e materiais avícola In: CONFERÊNCIA APINCO 2005 DE CIÊNCIAS E TECNOLOGIAS AVÍCOLAS, 2005, Campinas. Anais... Campinas: FACTA, 2005. v. 2, p. 223-228.
SAMPAIO, I. B. M. Estatística aplicada à experimentação animal. 3. ed. Belo Horizonte: FEPMVZ, 2007. 265 p.

SANT'ANA, T. M.; MONTEIRO, M. E. Z.; BIGNARDE, J. M. P.; UEDA, F. S.; PENHA, G. A.; PEREIRA, R. E. P. Salmonelose em animais silvestres e exóticos. Revista Científica Eletrônica de Medicina Veterinária, Garça, n. 11, p. 1-7, 2008.

SCALLAN, E.; HOEKSTRA, R. M.; ANGULO, F. J.; TAUXE, R. V.; WIDDOWSON, M. A.; ROY, S. L.; JONES, J. L.; GRIFFIN, P. M. Foodborne illness acquired in the United States major pathogens. Emerging Infectious Diseases, Atlanta, v. 17, n. 1, p. 7-15, 2011.

SHINOHARA, N. K. S.; BARROS, V. B.; JIMENEZ, S. M.; MACHADO, E. C. L.; DUTRA, R. A. F.; LIMA FILHO, J. L. Salmonella spp., importante agente patogênico veiculado em alimentos. Ciência \& Saúde Coletiva, Rio de Janeiro, v. 13, n. 5, p. 1675-1683, 2008.

UNIÃO BRASILEIRA DE AVICULTURA - UBABEF. Relatório anual 2014. São Paulo: ABPA, 2014. Disponível em: <http://www.ubabef.com.br/publicacoes $>$. Acesso em: 28 abr. 2014.

VAN DEN BOGAARD, A. E; STOBBERINGH, E. E. Epidemiology of resistance to antibiotics. Link between animals and humans. International Journal of Antimicrobial Agents, Amsterdam, v. 14, n. 4, p. 327$335,2000$.

VON RUCKERT, D. A. S.; PINTO, P. S. A.; SANTOS, B. M.; MOREIRA, M. A. S.; RODRIGUES, A. C. A. Pontos críticos de controle de Salmonella spp. no abate de frangos. Arquivo Brasileiro de Medicina Veterinária e Zootecnia, v. 61, n. 2, p. 326-330, 2009.

WORLD HEALTH ORGANIZATION - WHO. Risk assessments of Salmonella in eggs and broiler chickens. Geneva: WHO/FAO, 2002. Available at: <http://www. who.int/foodsafety/publications/micro/salmonella/en/>. Accessed at: 18 ago. 2014. 
